\title{
SUbJECT MARKING INTERRUPTED: PERTURBATIONS FROM THE DEVELOPMENT OF NORTHERN MAO'S FUTURE TENSE SUFFIX ${ }^{1}$
}

\author{
Michael Ahland \\ Houghton College and SIL International
}

\begin{abstract}
Northern Mao, an Omotic-Mao language of Ethiopia, exhibits three partially overlapping but distinct subject-marking paradigms in its verbal system: subject prefixes on realis verbs which correspond closely to free pronouns, subject suffixes on irrealis negative non-future verbs which exhibit regular changes from the realis prefixes, and a third, more divergent, subject suffix system on irrealis future verbs which exhibits an [m] form not attested as a person marker elsewhere in the language or extended family. It is argued (from internal evidence) that the irrealis future verbs developed from a periphrastic subordinate + final verb complexes and that the intrusive [m] was, at an earlier stage, part of a subordinating morpheme.
\end{abstract}

\section{Introduction}

Northern Mao is an endangered Omotic-Mao language of western Ethiopia (Bender 2003; Ahland 2012). The language is also known by the toponyms Bambassi and Didessa and the autonym Màwés Aats'è. There are at least four distinct languages within the Mao group of Omotic: Hozo, Seze, Ganza, and Northern Mao. While the exact position of Mao languages within the Omotic family has been a matter of some debate in the past (cf. Bender 1975, 1985, 1990, 2000, for summaries of the issues), both Bender and Hayward came to the conclusion that the Mao group is an independent branch of Omotic (Bender 2003:1; Hayward 2000:242). Bender noted that part of the problem with classification is that the Mao languages are the least documented within Omotic (Bender 2000:180), and Omotic itself is the least documented of the Afroasiatic groups (Hayward 2000). This study seeks to document and describe multiple subject marking paradigms found today in the Northern Mao verbal system; it also explores how the different paradigms may have developed.

Northern Mao is a rigidly OV-type language where subordinate clauses and medial/non-final verbs in clause chains precede finite final verbs (Ahland 2012:48); these final verbs carry obligatory bound pronominal marking which indicates the person and number of the subject. There are three different bound pronominal subject marking systems on Northern Mao final verbs. Of these three paradigmatic systems, two show widespread correspondence with one another: the first, involving prefixes on realis verbs, and the second, suffixes on irrealis negative non-future verbs. The other system, found on irrealis future verbs, has undergone changes where four of the

1 This research was funded in part through a Documenting Endangered Languages grant from the National Science Foundation (\#0746665) under the direction of Doris Payne. This work would not have been possible without the support of the Benishangul-Gumuz Culture Office in Asosa, the support of the Mao communities in Bambassi and Diddessa, especially Ato Yasin Ibrahim, Ato Mamo Shimagele, and Ato Tefera Ibrahim and the support of the Department of Linguistics at Addis Ababa University. 
nine person-number markers involve an [m] which is not reconstructable as part of the bound pronominal system. This paper offers a historical account as to how this [m] may have entered the paradigm and interrupted subject marking distinctions on the irrealis future verbs.

The study begins with an overview of the relevant data (section 2): an exploration of final verbs and their item-arrangements, their subject marking patterns and the correspondences between the subject markers and the free pronouns. Section 3 explores a possible historical account for how these systems could have developed through an examination of internal evidence. Section 4 demonstrates that the apparently innovated paradigm has been extended today into new territory, and section 5 offers some concluding remarks.

\section{Preliminary Concerns: An Overview of Relevant Data}

Before discussing possible historical developments, I must first examine certain relevant data to establish the subject marking patterns. These include the morphological make-up and functions of the realis and irrealis verb forms and their subject marking patterns (section 2.1), and the correspondences between these verbal subject markers and the free pronouns (section 2.2).

2.1 Realis and Irrealis Verbal Forms and Subject Marking. The most basic opposition in the Northern Mao verbal system is realis vs. irrealis. The distribution and function of the realis and irrealis verb forms in Northern Mao fits within Mithun's description of realis and irrealis (1999):

....realis portrays situations as actualized, as having occurred or actually occurring, knowable through direct perception. The irrealis portrays situations as purely within the realm of thought, knowable only through imagination [173].

The discussion below explores the item-arrangement of the realis and irrealis verb forms, their distributional functions within the language, and the subject marking patterns they exhibit. Realis and irrealis verbs are marked distinctly by their item-arrangement and not by any single morpheme. Most verbs in the language take one of these forms. Only verbs in the imperative and jussive and some (more nominalized) subordinate verbs are formed differently from these two basic patterns. The basic distinction in item-arrangement can be summarized as follows: the realis verb takes subject prefixes while the irrealis verb form takes subject suffixes and always requires one of several phonologically bound auxiliary (existential or copular) elements after the subject suffix. In fact, verb forms in Northern Mao may take multiple derivational and inflectional suffixes as well, but in general the order of these suffixes is the same (Ahland 2012:350); it is the subject marking and use of bound auxiliaries that formally distinguishes the irrealis verbal forms from the realis.

Table 1 illustrates the maximal expansion of the realis verb. The verb 'root' in Northern Mao is best understood as a stem, itself marked by tone as either finite or infinite (Ahland 2012:360ff). These stems can then receive derivational markers to form a broader stem. Thus, there is a stem 1 (tonally marked root) and a stem 2 (tonally marked root with derivational marker). In the realis verb, the finite verb stem is obligatorily preceded by subject marking prefixes, may be followed by derivational suffixes, and is then obligatorily followed by an utterance-type marker indicating either declarative or polar interrogative. A variety of other derivational and inflectional suffixes may also be present. 
Table 1. Realis Verb Item-Arrangement

\begin{tabular}{|c|c|c|c|c|c|c|c|c|c|}
\hline \multicolumn{2}{|c|}{$\begin{array}{c}\text { Inflectional } \\
\text { Prefixes }\end{array}$} & \multirow[b]{2}{*}{$\begin{array}{l}\text { Finite } \\
\text { Stem }\end{array}$} & \multicolumn{2}{|c|}{$\begin{array}{c}\text { Derivational } \\
\text { Suffixes }\end{array}$} & \multicolumn{5}{|c|}{ Inflectional Suffixes } \\
\hline 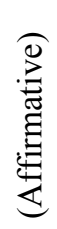 & 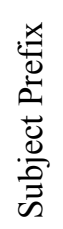 & & 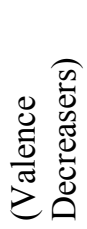 & 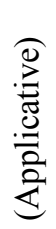 & 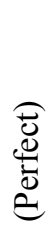 & 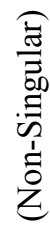 & 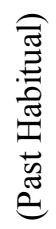 & 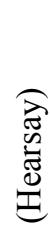 & 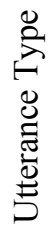 \\
\hline
\end{tabular}

In Northern Mao declarative and interrogative utterances, the realis verb form is used for events of the past or present, i.e. those which did or are currently taking place. The realis verb form itself expresses a non-future tense, which is not morphologically marked except for the itemarrangement of the verb form itself. That is, while the realis verb expresses non-future tense, the use of auxiliaries can allow for further specification as past or non-past. Generally speaking, verbs of activity are interpreted as past events (1-2) while verbs of cognition may be interpreted as past or present states (3-4).

(1) ha-tí-jé:ts" $"$-á

AFF-1SG-run-DECL

'I ran.' (in the past)

(2) kwalla ha-tí-jé:ts'- 'á

yesterday AFF-1SG-run-DECL

'I ran yesterday.'

(3) kwalla kí-gà $\int$ hì-wo:l-á

Yesterday come-PURP 2SG-want-DECL

'Yesterday, you (SG) wanted to come.'

(4) tóló kí-gà hì-wo:l-á

now come-PURP 2SG-want-DECL

'Now, you (SG) want to come.'

Examples (1-4) also serve to illustrate the 1SG and 2SG subject prefixes on the final realis verbs. Realis verbs with the first and second person DU and PL subject marking prefixes are illustrated below (5-8).

(5) han-tjam-á

1DU-count-DECL

'We (DU) counted.'

(6) ham-tjam-á

1PL-count-DECL

'We (PL) counted.' 
(7) háw-tjam-á

2DU-count-DECL

'You (DU) counted.'

(8) hàw-tjam-á

2PL-count-DECL

'You (PL) counted.'

Third person subjects are not marked on final realis verb forms (9-10).

(9) ha- $\varnothing$-tjam-á

AFF-3-count-DECL

'S/he counted.'

(10) ha- $\varnothing$-tjam-and-á

AFF-3-count-NSG-DECL

'They (NSG) counted.' (the NSG form is used for 3DU and 3PL)

Table 2 illustrates the arrangement of the irrealis future affirmative verb. The position of subject markers, the future tense suffix and the obligatory use of bound auxiliaries make up the most important differences between the irrealis future and the realis verb form in Table 1. In all irrealis verb forms, subject marking is suffixed, and in the irrealis future verbs, these subject suffixes immediately follow the future tense suffix and precede the bound auxiliary (Table 2).

Table 2. Irrealis Future Affirmative Item-Arrangement

\begin{tabular}{|c|c|c|c|c|c|c|c|c|c|c|}
\hline $\begin{array}{l}\text { Inflectional } \\
\text { Prefix }\end{array}$ & & $\begin{array}{l}\text { Deriv } \\
\text { Suf }\end{array}$ & $\begin{array}{l}\text { onal } \\
\text { es }\end{array}$ & \multicolumn{7}{|c|}{ Inflectional Suffixes } \\
\hline 昰 & $\begin{array}{l}\text { Finite } \\
\text { Stem }\end{array}$ & 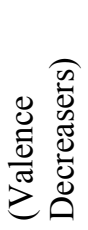 & 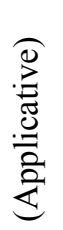 & 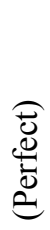 & 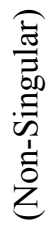 & 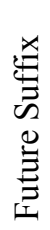 & 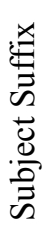 & 胥 & 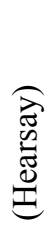 & 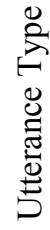 \\
\hline
\end{tabular}

The irrealis verb form is used for all future events (11-12), all counterfactual (morphologically affirmative but semantically contra-reality) non-future events (13), as well as all negative events (14-15).
háts’á
ha-jé:ts'-g-èm-bìj-á
General Future
tomorrow AFF-run-FUT-2SG-NPST:AUX-DECL
'You will run tomorrow.' 
(12)

tóló ha-jé:ts’-g-èm-n-á

Certain/Immediate Future ${ }^{2}$

now AFF-run-FUT-2SG-NPST:AUX-DECL

'You will run now.'

The irrealis counterfactual verb form is based on the irrealis future affirmative form but also involves a past auxiliary verb (13).
kwalla ha-mí-g-èm-bítè
Irrealis Counterfactual yesterday AFF-eat-FUT-2SG-PST:AUX
'You were gonna eat yesterday (but didn't).'

Counterfactuals, which are marked morphologically as future tense, also carry the past bound auxiliary verb. They are morphologically akin to the English counterfactual, which uses a combination of past auxiliary and future construction to indicate counterfactuality ("I was going to eat yesterday"). The presence of the future tense marker on counterfactuals is likely a relic of its grammaticalization pathway.

The irrealis negative future verb is marked by the combination of a negative suffix, positioned immediately before the future tense suffix, and the obligatory use of the infinitive verb stem (14). ${ }^{3}$

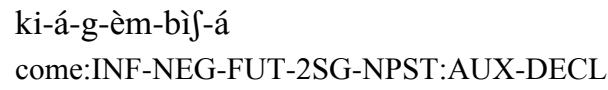

Irrealis Negative Future

In general, irrealis negative non-future verbs can be formed in the same way, but, of course, without a future tense suffix (15).

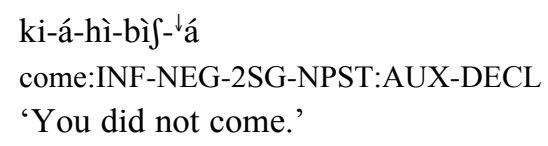

Irrealis Negative Non-Future

Examples (14) and (15) above demonstrate that not all irrealis verbs take the same suffixal subject marking. These two subject-marking paradigms found on irrealis verbs in Northern Mao are illustrated in their entirety in Table 3, below. One paradigm (Table 3, column 1) is used with irrealis negative non-future verbs and the other with irrealis future verbs (whether affirmative or negative) (column 2). The markers for $1^{\text {st }}$ person subjects are consistent with one another and also correspond clearly with the forms found on realis verbs (see examples 1 and 2 above and Table 4 below). The irrealis future subject suffixes for 2DU and 2PL are expressed by tone (which matches the tones found on the corresponding forms for the irrealis non-future verb) and also co-

2 The copular form $/-\mathrm{n} /$ is an important element which serves to indicate the disction between the certain/immediate future (12) and the general future (11). This copular form is featured as important evidence for the extension of innovated person marking (section 4).

3 For a thorough discussion of the use of finite vs. infinitive verb stems in final verbs, see Ahland (2012:360-374). In short, the infinitive verb stem is required in negative verb forms (future, non-future, hypothetical conditional and non-final/medial verbs). It is also required on various imperative and jussive forms as well as on the most highly nominalized subordinate verb forms. 
occur with a long vowel on the future suffix /-gà/: /-gà/ FUT + /- '/ 2DU and /-gà/ FUT + /- '/ 2PL. The subject marking is thus expressed through the modification of the future suffix:/-gă:/ FUT:2DU and /-gà:/ FUT:2PL.

Table 3. Irrealis Subject Markers in Verbal Words

\begin{tabular}{|c|c|}
\hline Negative Non-Future & Affirmative Future \\
\hline 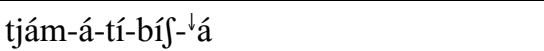 & ha-tjam-gà-t-bíf-á \\
\hline count:INF-NEG-1SG-NPST:AUX-DECL & AFF-count-FUT-1SG-NPST:AUX-DECL \\
\hline 'I did not count.' & 'I will count.' \\
\hline tjám-á-n-bíf-’á & ha-tjam-gà-n-bíf-á \\
\hline count:INF-NEG-1DU-NPST:AUX-DECL & AFF-count-FUT-1DU-NPST:AUX-DECL \\
\hline 'We (dual) did not count.' & 'We (dual) will count.' \\
\hline tjám-á-m-bì̀- ${ }^{\downarrow} a ́$ & ha-tjam-gà-m-bì J-á \\
\hline count:INF-NEG-1PL-NPST:AUX-DECL & AFF-count-FUT-1PL-NPST:AUX-DECL \\
\hline 'We (plural) did not count.' & 'We (plural) will count.' \\
\hline tjám-á-hì-bìj- ${ }^{\downarrow} a ́$ & ha-tjam-g-èm-bì -á \\
\hline count:INF-NEG-2SG-NPST:AUX-DECL & AFF-count-FUT-2SG-NPST:AUX-DECL \\
\hline 'You did not count.' & 'You will count.' \\
\hline tjám-á-w-bíf-的 & ha-tjam-gǎ:-bíf-á \\
\hline count:INF-NEG-2DU-NPST:AUX-DECL & AFF-count-FUT:2DU-NPST:AUX-DECL \\
\hline 'You (dual) did not count.' & 'You (dual) will count.' \\
\hline tjám-á-w-bì - ${ }^{\prime} a ́$ & ha-tjam-gà:-bìf-á \\
\hline count:INF-NEG-2PL-NPST:AUX-DECL & AFF-count-FUT:2PL-NPST:AUX-DECL \\
\hline 'You (plural) did not count.' & 'You (plural) will count.' \\
\hline tjám-wé-jà & ha-tjam-gà-m-bì)-á \\
\hline count:INF-NEG-COP & AFF-count-FUT-3-NPST:AUX-DECL \\
\hline 'S/he did not count.' & 'S/he will count.' \\
\hline tjám-ánd-wé-jà & ha-tjam-and-gà-m-bìj-á \\
\hline count:INF-NSG-NEG-COP & AFF-count-NSG-FUT-3-NPST:AUX-DECL \\
\hline 'They (dual/plural) did not count.' & 'They (dual/plural) will count.' \\
\hline
\end{tabular}

The 2 SG and all $3^{\text {rd }}$ person suffixes in the irrealis future involve the form /-m/ (with a floating $\mathrm{L}$ tone following the $[\mathrm{m}]$ - the $\mathrm{L}$ tone is observable on the following auxiliary). This bilabial form is not found on other morphemes marking the $2 \mathrm{SG}$ or $3^{\text {rd }}$ persons (prefixes, suffixes or free pronouns) elsewhere in the Northern Mao language. Today, the 1PL, with its inherited /-m/, and the $3 \mathrm{SG}^{4}{ }^{4}$ with its intrusive $[\mathrm{m}]$, are fully neutralized on the irrealis future verbs. The marker for

4 The irrealis negative non-future construction is a bit of a mixed bag, historically. The $3^{\text {rd }}$ person subject forms, for instance, involve the copula /jà/ as a bound auxiliary and use a different negative suffix /-wé/. This /-wé/ negative is related to a /-wá/ and /-wó/ negative markers found on medial/non-final verbs as well (Ahland 2012:585). 
2SG subject on irrealis future verbs involves a vowel change on the future suffix /-gà/ which precedes the [m]: /-gà/ FUT + /-èm/ 2SG > /-g-èm / FUT-2SG.

The full set of subject marking systems is summarized and compared to the free pronouns in section 2.2 , below.

2.2 Correspondences Between Verbal Subject Markers and the Free Pronouns. Table 4, below, illustrates correspondences between the full sets of free pronouns (column 1), realis verb prefixes (column 2), irrealis non-future negative subject suffixes (column 3) and irrealis future subject suffixes (column 4).

Table 4. Free Pronouns and Subject Markers on Final Verbs

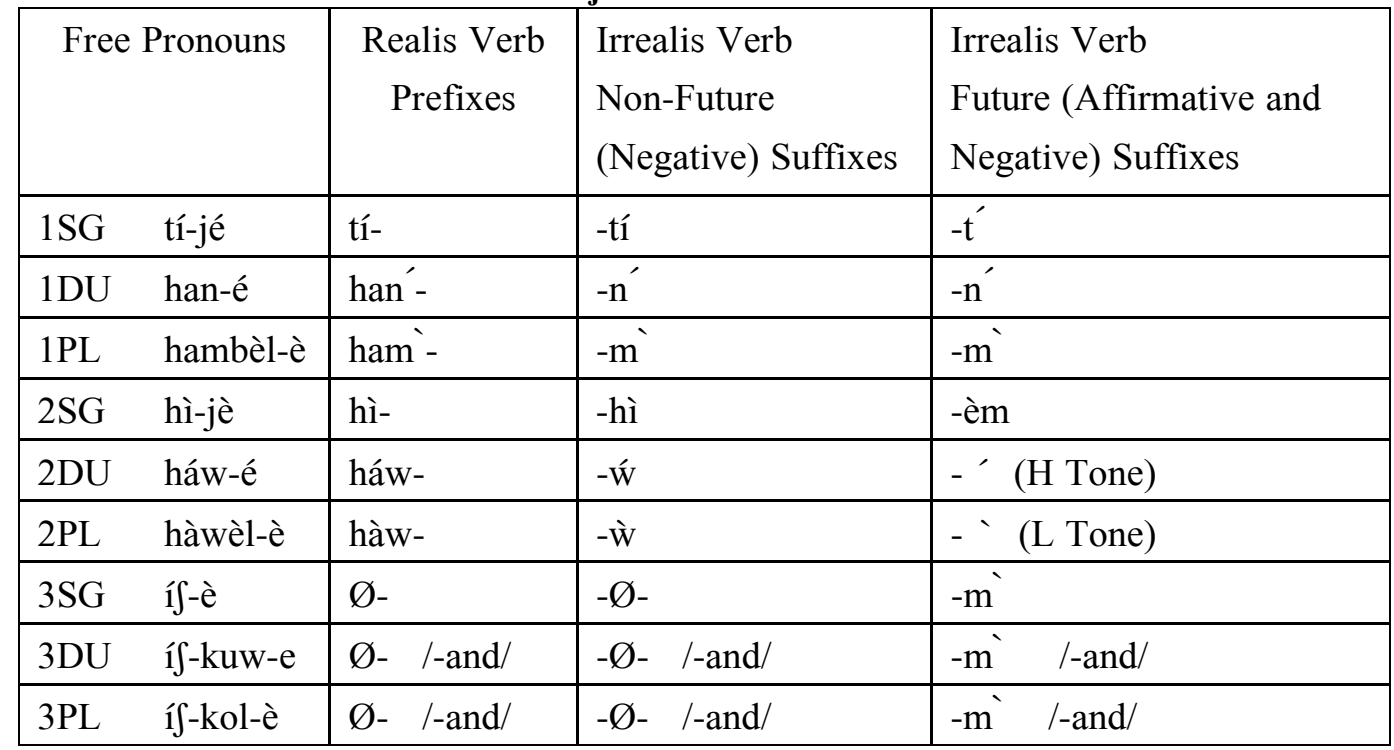

Of the three columns of verbal subject markers in Table 4, the realis verb subject prefixes show the clearest correspondences with the free pronouns across first and second person (singular, dual, and plural numbers) on the surface. The zero-marking on $3^{\text {rd }}$ person subject realis verbs may be due to a loss of subject markers. In fact, relativized verbs and other dependent forms do take $3^{\text {rd }}$ person subject markers which follow the pattern of the free pronouns (16-18) (cf. Ahland 2012:378-9).

(16) hí-tjam-t

mìs-nà ha-tí-int'-á

3SG-count-REL thing-OBJ AFF-1SG-see-DECL

'I saw the thing that $\mathrm{s} /$ he counted.'

(17) î́kuw-tjam-t mìs-nà ha-tí-int'-á

3DU-count-REL thing-OBJ AFF-1SG-see-DECL

'I saw the thing that they (DU) counted.' 


\section{(18) ífkol-tjam-t mìs-nà ha-tí-int'-á \\ 3PL-count-REL thing-OBJ AFF-1SG-see-DECL \\ 'I saw the thing that they (PL) counted.'}

Apart from the basic prefix/suffix position difference in subject markers for the realis and the irrealis negative non-future forms (Table 4, columns 2 and 3), the primary difference in shape is the lack of a [ha] sequence on the $1^{\text {st }}$ and $2^{\text {nd }}$ person non-singular suffix forms in column 3 . This [ha] is in fact intrusive to the person marking system. Its source is the affirmative verbal prefix /ha-/ (Ahland 2013). The [ha] sequence is the result of a fusion of a verbal AFF prefix (/ha-/) with the 1DU/PL and 2DU/PL subject prefixes. The free pronouns developed from these newly fused bound subject prefixes, allowing the entry of [ha] to the pronominal inventory (Ahland 2012:246ff). If one ignores the intrusive [ha] form found on the $1^{\text {st }}$ and $2^{\text {nd }}$ person non-singular realis verb prefixes, the similarities can be extended to include column 3 as well (i.e. the realis verb prefixes and the irrealis verb non-future negative suffixes).

The irrealis future suffixes in column 4 also lack the [ha] sequence which is present on the realis verb prefixes (column 2) and on the corresponding free pronouns (column 1). Between the two sets of irrealis verb suffixes (columns 3 and 4), however, only the first person suffixes are obviously similar in shape. The irrealis future verb's 2DU and 2PL subject marking are expressed by tonal distinctions alone, and $2 \mathrm{SG}$ and $3^{\text {rd }}$ person forms all involve an $[\mathrm{m}]$ consonant that does not correspond to any of the free pronouns or the other markers of subject.

It is the intrusive appearance of this $[\mathrm{m}]$ marking $2 \mathrm{SG}$ and $3^{\text {rd }}$ person on irrealis future verbs which demands explanation. While the /-m/ 1PL suffix in column 3 corresponds to the 1PL free pronoun in column 4 (disregarding the [ha]) and is consistently used to express 1PL across the pronominal and verbal systems, the $/-\mathrm{m}^{\prime} /$ in the $2 \mathrm{SG}$ and $3^{\text {rd }}$ person forms has come frome outside.

Essentially, where the /-gà/ future tense suffix in Table 3 is found, the innovated $2^{\text {nd }}$ and $3^{\text {rd }}$ person markers are also found (i.e. those which do not correspond to the free pronouns in column 1 of Table 4). Additionally, where the /-gà/ form is not attested (i.e. the non-future irrealis), markers are found that correspond to what is used elsewhere in the language (i.e. corresponding with free pronouns or realis verb prefixes, etc.). And so, now, after a brief overview of the most relevant aspects of the pronominal and verbal systems, the primary question for this study again arises: what gave rise to the inconsistencies in the subject-marking paradigm?

\section{The Sources of the Irrealis Verb and the Future Tense Suffix}

The discussion below will show how the historical development of the irrealis verbal word and, more specifically, how the development of the future tense suffix could have sparked the subject marking innovations found today in the irrealis future verb.

The irrealis verb may be used with the future tense suffix on future verbs (affirmative (11 and 12) and negative (14)) and on counterfactuals (13), or without the future tense suffix on negative non-future verbs (15). The item-arrangement of the irrealis future form suggests that this verb form may have been derived from a subordinate verb followed by a fully finite existential (/bi $/$ /) or copular $(/ \mathrm{n} /)$ verb. There are two facts which lend credence to this hypothesis.

First, today’s future tense suffix /-gà/ is similar to a purposive subordinate marker/-gàj/ found on purpose adverbials (19) as well as on some complements (20). 
(19)

kà:1-là mí-gà tí-kí-ti-á

porridge-OBJ eat-PURP 1SG-come-PF-DECL

'I have come to eat porridge.'

(20)
mì-gàf-nà
ha-tí-ts'é:l- vá
eat:INF-COMP-OBJ
AFF-1SG-finish-DECL

'I finished eating.'

Purpose clauses are "intrinsically future-oriented" (Schmidtke-Bode 2009:43) and have been shown to be among the attested sources of future constructions, when combined with suitable main verbs which then become auxiliaries (2009:181). Bybee et al. (1994:263-75) also discuss the fact that purpose clauses and notions like intention and desire are "compatible or harmonic" with the development of future tense.

The second fact that supports a periphrastic source for the irrealis future verb is that the subject suffixes which follow the /-gà/ FUT suffix immediately preceded bound auxiliaries, which have been grammaticalized from lexical verbs. In Northern Mao, verbal prefixes are used to mark subjects on realis verbs. It is only on irrealis verbs that the subject is marked by suffixes and these are always immediately followed by bound auxiliaries. Perhaps the subject suffixes were once subject prefixes on finite final verbs that became bound auxiliaries. And in fact, negative verb forms in Northern Mao (all of which involve an irrealis pattern) offer additional support for a periphrastic history. Negative forms involve an infinitive verb stem (not a finite stem), followed by a negative marker and then the subject marker + auxiliary + utterance marker (cf. column 1 of Table 3). This pattern is consistent with a nominalized (hence the infinitive verb stem) subordinate verb structure followed by a fully-finite final verb with its subject prefixes. Perhaps the negative marker itself was a nominalizer/subordinator in history.

But this still leaves the question: why would older subject prefixes attached to grammaticalized auxiliaries undergo changes like the addition of an intrusive [m] and deletion of the $[\mathrm{w}]$ in the cases of the 2DU/PL forms (cf. Table 4) as the purported subordinate + final verb complex collapsed into a single word?

3.1 Irregularity as a Key to the Past. Internal irregularities in future tense marking in Northern Mao could provide the answer to the question above. The future tense suffix /-gà/ appears to have been /-gàm/ at an earlier stage in its development. Internal irregularities found in the future relative clause preserve what appears to be an older [m] which clearly does not mark $3^{\text {rd }}$ person, as shown by the $1^{\text {st }}$ person future relative clause below $(21$ and 22$){ }^{5}$
ha-tí-kí-gàm-b-t
ki-nà
tí-kòj-á
AFF-1SG-come-FUT-NPST:AUX-REL come:INF-OBJ
1SG-believe-DECL
'I believe that I will come.'

\footnotetext{
5 The data in (21) constitutes a relative clause, despite the English gloss. Northern Mao uses a relativized verb + infinitive verb marked with case (which serves as the head noun) to form these particular types of complements (cf. Ahland 2012:634).
} 
(22)
tí-mì-á-gàm-b-t
ka:l-là
1SG-eat:INF-NEG-FUT-NPST:AUX-REL porridge-OBJ
tí-n ha-mí-gà-m-bìj-á
1SG-GEN brother-SBJ AFF-eat-FUT-3-NPST:AUX-DECL

'My brother will eat the porridge that I will not eat.'

The $[\mathrm{m}]$ is present on the relativized verb's future tense marker regardless of the subject of the relative clause (23).
hí-hadèm-gàm-b-t
es-ì
mí-gà-m-bìf-á
3SG-work-FUT-NPST:AUX-REL person-SBJ
eat-FUT-3-NPST:AUX-DECL
'The person who will work will eat.' (an aphorism)

As can be seen in examples (21-23), subjects on relative clauses are marked only as prefixes, of the same shape as the realis verb prefixes (Table 4). As demonstrated in examples (16-18 above), relative clauses which have a $3^{\text {rd }}$ person subject (regardless of whether they are future or nonfuture) exhibit subject prefixes that correspond to the morphological shapes of the free pronouns. That is, where the realis verb has a zero marker for $3^{\text {rd }}$ person subjects, subordinate verbs mark the $3^{\text {rd }}$ person subject overtly with forms which correspond to the free pronouns (column 1 of Table 4). Subject prefixes are also used for non-final/medial verbs in clause chains (Ahland 2012:560ff).

In short, then, in future relative clauses in (21-23), the [m] on the /-gàm/ future suffix is found, regardless of what subject prefix precedes the verb stem; on these relativized verbs, it cannot be parsed separately from the future suffix. The $[\mathrm{m}]$ on the /-gàm/ future tense marker is found only in those conjugations where subject prefixes are used (i.e. not where subject suffixes may be found following the future tense suffix).

3.2 From Periphrastic Construction to New Verbal Word. The facts presented above suggest that the irrealis future verb developed from a periphrastic construction, where a subordinate verb marked with a subordinator suffix /-gàm/ (likely related to today's purposive /-gàf/ suffix) ${ }^{6}$ preceded a fully finite existential or copula which was itself marked with subject prefixes (24 and 25).

Stage 1 (Reconstructed): Subordinate Verb and Finite Final Verb

$\begin{array}{lll}\text { (24) kàil-là } & \text { mí-gàm } & \text { tí-bíf-'á } \\ \text { porridge-OBJ } & \text { eat-PURP } & 1 \text { SG-EXIST-DECL }\end{array}$

Literal reconstructed meaning: 'I am in order to eat porridge.'

(effective force: 'I intend to eat porridge.')

6 An account for how /-gà $/$ could have developed from an older/-gàm/ is taken up in section 5. 
(25)

$\begin{array}{ll}\text { héz-gàm } & \varnothing \text {-bíf- }{ }^{-a ́} \\ \text { hit-PURP } & 3 \text {-EXIST-DECL }\end{array}$

Literal reconstructed meaning: 'S/he is in order to hit.'

(effective force: 'She intends to hit.')

During this stage, irrealis (and future) were perhaps expressed through such a periphrastic construction. Northern Mao's internal evidence (as in examples 21-23, above) suggests that the form /-gàm/, likely a subordinator, was at some point reanalyzed as a future tense marker (as in $26-27)^{7}$

Stage 2 (Reconstructed): /-gam/ becomes future tense suffix

(26)

$\begin{array}{lll}\text { kàil-là } & \text { mí-gàm } & \text { tí-bíf- }{ }^{-} a ́ \\ \text { porridge-OBJ } & \text { eat-FUT } & 1 \text { SG-EXIST-DECL }\end{array}$

'I will eat porridge.'

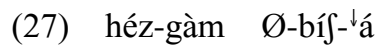

hit-FUT 3-EXIST-DECL

'S/he will hit.'

It does appear that the /-gàm/'s final consonant [m], with its L tone, underwent two different changes in a third stage, while the periphrastic construction collapsed into a single word. These two changes were dependent on the phonological shape of the subject markers which followed the $[\mathrm{m}]$.

First, in instances where the following subject markers began with consonants other than $[\mathrm{h}]$, the /-gàm/'s final [m] and its L tone were simply lost (examples 28-32). ${ }^{8}$

(28) ha-héz-gà-t-bíf-á $/-t^{\prime} / 1 S G$

AFF-hit-FUT-1SG-NPST:AUX-DECL

'I will hit.'

(29) ha-héz-gà-n-bíf-á

$/-n^{\prime} / 1 D U$

AFF-hit-FUT-1DU-NPST:AUX-DECL

'We (dual) will hit.'

7 Beginning with example (28), the /ha-/ affirmative prefix is shown on the affirmative irrealis verbs. The internals evidence suggests that the /ha-/ affirmative prefix was not used on final verbs in these periphrastic constructions. While one can't be sure why this was the case, it is clear that the /ha-/ prefix interfered with subject prefixes on realis verbs (fusing with the 1DU/PL and 2DUPL prefixes and sparking the development of new pronouns, see Ahland 2012:243-254 and Ahland 2013). And there is no evidence of any [ha] form anywhere in the subject markers on irrealis verbs. For whatever reason, one can say with certainty, the /ha-/ was not involved in the early stages of the irrealis verb forms.

8 Again, the 1PL /-m/ marker is not related in any way to the [m] of the /-gàm/ suffix. 1PL marking in Northern Mao always involves the bilabial nasal, even in realis verb prefixes (Table 4). 
(30) ha-héz-gà-m-bìj-á

/-m / $1 \mathrm{PL}$

AFF-hit-FUT-1PL-NPST:AUX-DECL

'We (plural) will hit.'

And more specifically, in the case of 2DU and 2PL, which are marked elsewhere with /-w'/ and /-̀̀/ respectively, the [w] consonant triggered the loss of the [m] from/-gàm/. Then, a later loss of the $[\mathrm{w}]$ resulted in compensatory lengthening of the future suffix's vowel, with maintenance of the $\mathrm{H}$ tone of the 2DU in the form of a rising tone (low followed by high) on the future suffix (31-32).

(31) ha-héz-găi-bíf-á

/-'/ 2DU with long vowel

AFF-hit-FUT:2DU-NPST:AUX-DECL

'You (dual) will hit.'

(32) ha-héz-gà:-bíf-á

ハ / 2PL with long vowel

AFF-hit-FUT:2PL-NPST:AUX-DECL

'You (plural) will hit.'

Note that the vowel of the remaining [ga] was lengthened only in the instances where the 2DU and 2PL [w] forms were lost (Table 4). The loss of the [m], which occurred across five person subjects, was not the trigger for the lengthening of the [a] vowel.

In the $3^{\text {rd }}$ person and $2 \mathrm{SG}$ conjugations, the $[\mathrm{m}]$ of the /-gàm/ suffix was not lost; rather it was itself reanalyzed as a subject suffix. The motivation for this reanalysis is most evident in the $3^{\text {rd }}$ person conjugations, where the subject is marked with a zero prefix on realis verbs (Table 4, cf. my reconstructed examples 25 and 27). In the case of third person, there was no phonological material to trigger the loss of the $[\mathrm{m}]$ (as was the case with the $1^{\text {st }}$ person and 2DU and 2PL conjugations). The $[\mathrm{m}]$ simply filled the gap where no subject marker had been.

Stage 3: The reanalysis of [m']

(33) ha-héz-gà-m-bìj-á

3SG

AFF-hit-FUT-3-NPST:AUX-DECL

'S/he will hit.'

(34) ha-héz-and-gà-m-bìj-á

3DU/PL (i.e. non-singular)

AFF-hit-NSG-FUT-3-NPST:AUX-DECL

'They will hit.'

The 2SG suffix, on the other hand, was likely /-hì/ (or perhaps only a vowel in this environment, after an [m]). The [i] vowel of the 2 SG suffix impacted the vowel of the future suffix /-gà/, producing the shape [gèm] with /-èm/ then serving as a marker of 2SG (35).

(35) ha-héz-g-èm-bì -á 2SG

AFF-hit-FUT-2SG-NPST:AUX-DECL

'You (singular) will hit.' 
In short, the irrealis future verb may have developed from a periphrastic construction where the subordinate verb was marked with /-gàm/ and was followed by a fully finite final verb marked with subject prefixes. The collapse of this complex construction into a single verb form resulted in modified, and in some cases, new subject-marking patterns for $2^{\text {nd }}$ and $3^{\text {rd }}$ persons.

\section{An Extension of Subject Marking Innovation}

As seen in example (12) above, there is another irrealis future verbal construction which is used to communicate a sense of certainty or immediacy with regards to future events (cf. Ahland 2012:448). The verbal word is formed in the same way as the irrealis future constructions illustrated above (cf. Table 2 and examples 11 and 12), but instead of using the auxiliary /bij/, which was grammaticalized from a finite existential verb, the auxiliary is filled by the copular form /-n/. Examples (36-38) provide examples of the irrealis certain/immediate future verb construction (as opposed to the irrealis general future construction which was featured in the historical scenario in section 3).

(36) háts’à ha-kí-gà-t-n-á

Tomorrow AFF-come-FUT-1SG-NPST:AUX-DECL

'I will come tomorrow.' (with certainty)

ki:m-na tjam-gà-m-n-à

money-OBJ count-FUT-3-NPST:AUX-DECL

'He will count the money.'

(said with certainty regarding someone who was paid for work)

(38) háts'à tí-ná ha-int'-g-èm-n-á

tomorrow 1SG-OBJ AFF-see-FUT-2SG-NPST:AUX-DECL

'You will see me tomorrow.' (with certainty)

What's particularly interesting about this verb form is that the auxiliary /-n/ appears to come from the frozen copula /ne/ (Ahland 2012:462-3). No evidence has been found to suggest that this copula or any of the other monosyllabic copular forms in Northern Mao (such as the /jà/ copula in the irrealis negative non-future $3^{\text {rd }}$ person forms in Table 3 ) can take subject markers. They are not conjugated for person, number, or tense/aspect.

These facts suggest that the irrealis certain/immediate future verb form developed after the irrealis general future verb form, and the significance of this is that the subject markers themselves appear to be an active paradigm, having become productive in a new morphological environment (i.e. in a new verbal construction before a copula that does not appear to have ever taken subject prefixes). Given that the /nè/ copula, like other monosyllabic copulas in Northern Mao, does not take person marking, it seems very unlikely that subject markers could have come into this verb form as prefixes attached to the copula as it was being grammaticalized as an auxiliary. In short, then, the irrealis certain/immediate future construction provides evidence that the innovated subject marking pattern of the irrealis general future verb has been extended into newer territory. 


\section{Conclusions and Further Considerations}

The main thrust of this paper has been to identify a plausible explanation for the divergent subject marking found on irrealis future verbs, relative to markers of subject on other irrealis and realis verb forms in Table 1. The non-future and the future forms of the irrealis verb both appear to have involved some analytical / periphrastic history where an auxiliary verb joined with a preceding subordinate form. It is here suggested that the irrealis future developed from the fusion of a purposive subordinate structure with a finite existential verb which carried its own subject prefixes (like all realis verbs do today). The irrealis negative non-future verb appears to have developed from a subordinate structure (marked with /-á/ NEG) followed by a finite final verb which carried subject prefixes. ${ }^{9}$ Today, the subject marking found on these irrealis negative non-future verbs still corresponds closely to the subject marking on realis verbs (see ex. 15 and the first column of Table 3 ). It is only when the future tense suffix is used (e.g. in irrealis general future, certain/immediate future and counterfactual verbs) that the innovated pattern is found.

The historical scenario presented in section 3 suggests that the /-gàm/ old future suffix (preserved today in future relative clauses) is likely related to the /-gà $/$ purposive suffix. But if this is the case, what could account for the difference in the shape of the purposive suffix today? One possible answer lies in the use of / Jalè/ 'way' as a relational noun and even a postposition in movement predications.

es-î kjat'-Sal-nà ha-hów-j- -'á

person-SBJ house-way-OBJ AFF-go-AWAY-DECL

'A man went to the house.'

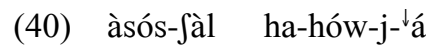

Asosa-way AFF-go-AWAY-DECL

'S/he went to Asosa.'

It may be that /- $\mathrm{fal} /$ began to be used as part of the purpose adverbial construction. The connection between semantics of movement, purpose, and even futurity would support this possibility.

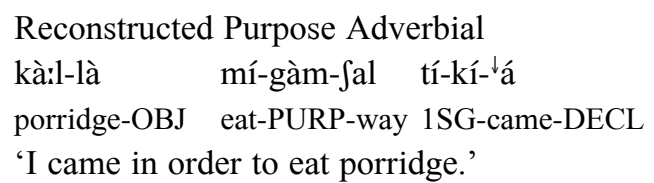

9 Given the morphological patterns in the irrealis negative non-future verb, it seems reasonable to suggest that the /-á/ form was a nominalizer. All negative verb conjugations in Northern Mao require an infinitive verb stem, marked tonally as distinct from the finite verb stem (Ahland 2012:360). The irrealis negative future also includes the infinitive verb stem and negative suffix (cf. Table 3) but with the addition of the future tense suffix after the negative/-á/. And of course, in the case of the future verb form, the subject markers show the expected innovations. 
Perhaps the final [m] of the /-gàm/ was lost before the [J] of / $\mathrm{Jal} /$ and the ending eventually contracted from /-gàfal/ > /-gàj/. It is impossible to be completely certain of the details at this point, but the fact that the purposive construction involves a [gà] sequence acting as a subordinator with semantics that clearly relate to futurity seems too likely a source to be ignored.

The reanalysis of /-gàm/, from a subordinator to a future tense suffix, provides us with an explanation for the two sets of suffixes found on irrealis verbs in Table 4. First, where no future suffix is found, irrealis subject suffixes correspond regularly with the subject prefixes on realis verbs. And in verbal forms which exhibit the future suffix, innovations are found which involve an intrusive $[\mathrm{m}]$ in $3^{\text {rd }}$ person and 2SG forms and additional changes in the 2DU and 2PL forms. This account builds on irregularities preserved in the future relative clause to describe how new irregularities developed in the verbal system, effectively interrupting what appears to have been a relatively regular subject-marking system.

\section{Abbreviations}

\begin{tabular}{|c|c|c|c|}
\hline 1 & First person & $\mathrm{L}$ & L tone \\
\hline 2 & Second person & NEG & Negative \\
\hline 3 & Third person & NPST & Non-past \\
\hline AFF & Affirmative & NSG & $\begin{array}{l}\text { Non-singular (dual } \\
\text { and plural) }\end{array}$ \\
\hline AUX & Auxiliary & OBJ & Object \\
\hline AWAY & Translocative directional & PASS & Passive \\
\hline COMP & Complementizer & $\mathrm{PF}$ & Perfect \\
\hline DECL & Declarative & PL & Plural \\
\hline EXIST & Existential verb & PST & Past \\
\hline DU & Dual & PURP & Purposive \\
\hline FUT & Future & REL & Relativizer \\
\hline GEN & Genitive & SBJ & Subject \\
\hline $\mathrm{H}$ & $\mathrm{H}$ tone & SG & Singular \\
\hline
\end{tabular}

\section{References}

Ahland, Michael B. 2012. A Grammar of Northern Mao (Màwés Aas'è). Eugene, OR: University of Oregon, $\mathrm{PhD}$. dissertation.

Ahland, Michael. 2013. "Degrammaticalization in Northern Mao's pronominal innovations: from subject prefix to full pronoun." Paper presented at the $87^{\text {th }}$ Annual Meeting of the Linguistic Society of America, Boston, January.

Bender, M. Lionel. 1975. The beginnings of ethnohistory in western Wellegga: the Mao problem. Patterns in language, culture and society: Sub-saharan Africa. OSU Working Papers in Linguistics 19.125-141.

Bender, M. Lionel. 1985. Gumuz, Koman, Mao and Omotic. Studies in African Linguistics (supplement) 9.19-21. 
Bender, M. Lionel. 1990. The limits of Omotic. Omotic language studies, ed. by Richard J. Hayward. London: School of Oriental and African Studies, University of London.

Bender, M. Lionel. 2000. Comparative morphology of the Omotic languages.

Muenchen: Lincom Europa.

Bender, M. Lionel. 2003. Omotic lexicon and phonology. (Published by author.)

Bybee, Joan, Revere Perkins, and William Pagliuca. 1994. The Evolution of Grammar: Tense, Aspect, and Modality in the Languages of the World. Chicago and London: The University of Chicago Press.

Hayward, Richard J. 2000. The 'empty quarter' of Afroasiatic. Research in Afroasiatic grammar II: Selected papers from the Fifth Conference on Afroasiatic Languages (Paris), ed. by Jacqueline Lecarme, 241-61.

Amsterdam: John Benjamins Publishing Company.

Mithun, Marianne. 1999. The Languages of Native North America. Cambridge: Cambridge University Press.

Schmidtke-Bode, Karsten.2009. A Typology of Purpose Clauses. Typological Studies in Language, 88. Amsterdam/Philadelphia: John Benjamins Publishing Company.

Dr. Michael Ahland

Houghton College

SIL International

michael_ahland@sil.org
Received: 31 October 2013

Accepted: 4 April 2014

Revisions: 2 October 2014 